\title{
HYDRODYNAMICS OF COTTON FILTRATION DRYING
}

\author{
Volodymyr Atamanyuk ${ }^{1,}$, Zoriana Gnativ ${ }^{1}$, Diana Kindzera ${ }^{1}$, \\ Dauren Janabayev ${ }^{2}$, Alisher Khusanov', Botagoz Kaldybaeva ${ }^{2}$
}

https://doi.org/10.23939/chcht14.03.426

\begin{abstract}
The work deals with the results of using the cotton fiber as the purest and most natural cellulose, as well as a raw material for the production of various chemical products. The necessity of cotton fiber preparation for its use in the chemical industry and expediency of its drying via a filtration method has been substantiated. The geometrical parameters of individual cotton villi, physical and mechanical characteristics of the layer were experimentally investigated. Under the action of pressure drop the effect of the cotton fiber layer height on the porosity, equivalent diameter, through which the heat agent is filtered, the specific surface area and the pressure loss were analytically determined. The experimental results regarding the pressure loss in a layer of cotton fiber during filtration drying are presented from the standpoint of the internal problem of hydrodynamics.

The results of heat agent filtration through a cotton layer at different weights and heights of the layer are presented as a functional dependence $\Delta P=f\left(v_{0}\right)$, and changes in the layer porosity as $\varepsilon=f\left(v_{0}\right)$. The generalization of the experimental data is represented as a dimensionless complex $\mathrm{Eu}=f(\mathrm{Re})$, and the dependence of the hydraulic resistance coefficient as a function of the Reynolds number $\xi=f(\mathrm{Re})$. The results obtained in a dimensionless form make it possible to predict the energy costs for creating a pressure drop (under the same hydrodynamic conditions) when designing a new drying equipment.
\end{abstract}

Keywords: hydrodynamics, filtration drying, criterion dependencies, cotton fiber.

\section{Introduction}

In recent years, the number of studies on new promising materials based on natural polymers as a renewable raw material of plant origin has increased. Cotton is a constantly renewable source of raw materials

\footnotetext{
${ }^{1}$ Lviv Polytechnic National University, 12, S. Bandery St., 79013 Lviv, Ukraine

${ }^{2}$ M. Auezov South Kazakhstan State University,

5, Tauke khan Ave., 160012 Shymkent, Kazakhstan

atamanyuk@ukr.net

(C) Atamanyuk V., Gnativ Z., Kindzera D., Janabayev D., Khusanov A., Kaldybaeva B., 2020
}

for the chemical industry. It consists of cellulose - a natural linear polysaccharide [1-3]. Cellulose is one of the most common natural polymers with a linear structure of macromolecules, which contains three hydroxyl groups of an alcoholic nature. Alcoholates, ethers and esters of cellulose are obtained by its chemical modification. Methyl-, ethyl-, carboxymethyl-, oxyethyl- and benzylcellulose are widely used in chemical technology. Via their reaction with nitric acid the mono-, di- and trinitrate celluloses (pyroxylin), as well as acetates, acetobutyrates, acetopropionate and cellulose tripropionates, etc. are obtained.

It is known [4-5] that the chemical treatment of cotton pulp is generally difficult because this natural polymer does not melt or dissolve in usual solvents due to the presence of hydrogen bonds and partially crystalline structure, but the physical properties of cellulose can be significantly modified by derivatization. During the cellulose hydrolysis, a light microcrystalline cellulose is obtained, the degree of crystallinity of which is over $80 \%$, and the average length of crystals is $7-10 \mathrm{~nm}$. When changing the cellulose derivatives properties it is possible to significantly expand the area of its application in the manufacture of modern protective coatings for the controlled release of active substances, optical films, liquid crystal displays (LCD), membranes, artificial glass, cellophane, photographic and film films, linoleum, arthrolic composites, means of individual absorption, etc.

According to its structure, the raw cotton is a heterogeneous material, which consists of three main components - the cotton fiber itself, the peel and the seed kernel [6]. Cotton fiber has a developed capillary-porous structure, which consists of cavities among fibrils, interfibrillar pores, fiber channels and pores with a diameter of several microns, so it is a hygroscopic material, and its natural humidity can exceed $12 \%$. In general, cotton is a colloidal capillary-porous body and contains all types of moisture [7, 8]. To obtain a qualitative raw material for the chemical industry, the moisture content of cotton should be less than 8-9\%, and for cellulose nitration its moisture content should not exceed $0.5-1 \%$, hence a cotton fiber must be dried [9].

It is known that the moisture removal from the material is accompanied by breaking its bond with the 
material, which consumes a significant amount of energy. Currently, the drying drums of 2SB-10, SBT, SBO types are used for drying cotton. The kiln gases used in drying drums as a heat agent degrade the quality of raw material and contaminate it with combustion products. In addition, rotating drying drums are characterized by the high metal and energy consumption.

Analysis of literature sources $[7-8,10]$ allows us to conclude that there is no comprehensive and systematic approach to the intensification of drying processes of cotton fiber, taking into account that it is a thermolabile material containing mainly bound moisture and, and the drying process takes place in the second period.

Theoretical analysis and design of drying systems are complicated by a number of factors, including the simultaneous heat and mass transfer to the surface and inside the material (there are over 18 different mechanisms of moisture transfer). The change in the moisture content and material temperature is determined by the heat and mass transfer between the material surface, the environment and an inner part of the dried material.

The filtration drying is one of the most intensive methods of removing both free and bound moistures. Due to the pressure drop, the heat agent is filtered through the porous structure of the wet material, which is placed on the perforated baffle in the direction of "wet material perforated baffle" [13]. The rate of the heat agent movement in the pores and channels of the stationary layer of wet material determines the thickness of the boundary layer (hydrodynamic, thermal and diffusion) and, accordingly, the values of heat and mass transfer coefficients. In addition, the surface of heat and mass transfer is the total surface of pores and channels through which the heat agent is filtered. The filtration rate is determined taking into account the process feasibility and the fact that the increase in rate increases the pressure loss. Moreover, the actual rate of the heat agent movement relatively to the layer elements is much higher than in the case of drying by any other methods (in a fluidized bed, in pneumatic dryers, etc.). The large surfaces of heat and mass transfer and the heat agent rate in the pores and channels of the stationary layer provide high coefficients of heat and mass transfer and, correspondingly, the intensity of filtration drying.

At the same time, the total energy costs for the filtration drying process consist of pressure loss in the stationary layer and agent (air) heating to a predetermined temperature. Taking all above mentioned into consideration, it is important to establish the dependence of the pressure loss in the wet cotton fiber layer on the fictitious filtration rate of the heat agent, which is an important factor determining the energy costs for hydrodynamics, intensity and cost-effectiveness of filtration drying.
The movement of the gas flow through the porous structure of the material is a mixed problem of hydrodynamics which has no theoretical basis. To describe the hydrodynamics of gas movement through the porous structure of a material, the researchers use theoretical dependencies of internal or external problem [14]. Taking into account the dependence of heat agent rate on the intensity of heat and mass transfer, in this work we present the results of experimental studies regarding the pressure loss in the cotton fiber layer in terms of the internal problem of hydrodynamics.

\section{Experimental}

\subsection{Objects and Research Methods}

The object of the experimental studies was freshly harvested cotton fiber. The chemical composition is: $95-98 \%$ of cellulose, about $1 \%$ of minerals, the rest is natural waxes, fats and proteins. JSM-6490LV raster electron microscope was used to determine the average size of cotton villi. More than 100 samples of randomly selected cotton villi were analyzed. The cotton fiber under study (Fig. 1) consists of thin villi with a length of $25-45 \mathrm{~mm}$, an average width of $24.8 \mu \mathrm{m}$ (170 mtex) and an average thickness of $4.51 \mu \mathrm{m}$. The cotton fiber density is $1520 \mathrm{~kg} / \mathrm{m}^{3}$.

\subsection{Theory}

As shown by the experiments, when applying the pressure drop to provide proper filtration rate of the heat agent, the stationary layer of cotton fiber changes its height due to the small stiffness of the individual fibers chaotically placed in the experimental container. The result is a change in the equivalent diameter of the channels through which the heat agent moves, as well as the layer porosity and the actual rate. The change in the actual rate of the gas stream $(v)$ leads to the increase in pressure loss $(\Delta P)$. The decrease in the fiber layer height $(H)$ increases a bulk density $\rho_{l}$ (analogue of bulk density for dispersed materials). In other words: $H=f(\Delta P)$; $d_{e}=f(\Delta P) ; \varepsilon=f(\Delta P) ; \rho_{l}=f(\Delta P) ; \Delta P=f(v)$ For all that, the weight of the fiber sample $\left(G_{v}\right)$ and the external surface of all cotton fibers remain constant.

The pressure loss in the porous stationary layer is determined on the basis of the known Darcy-Weissbach dependence, since it takes into account all possible variables related to the experiment $[13,14]$ :

$$
\Delta P=\lambda_{l} \cdot \frac{H}{d_{e}} \cdot \frac{\rho v^{2}}{2}
$$

where $\lambda_{l}$ is a coefficient of hydraulic friction; $\Delta P$ is a pressure loss in the material layer, $\mathrm{Pa} ; H$ is a layer height, $\mathrm{m} ; d_{e}$ is the equivalent diameter of pores and channels through which the heat agent is filtered, $\mathrm{m} ; \rho$ is a heat agent density, $\mathrm{kg} / \mathrm{m}^{3} ; v$ is the actual rate of the heat agent movement, $\mathrm{m} / \mathrm{s}$. 

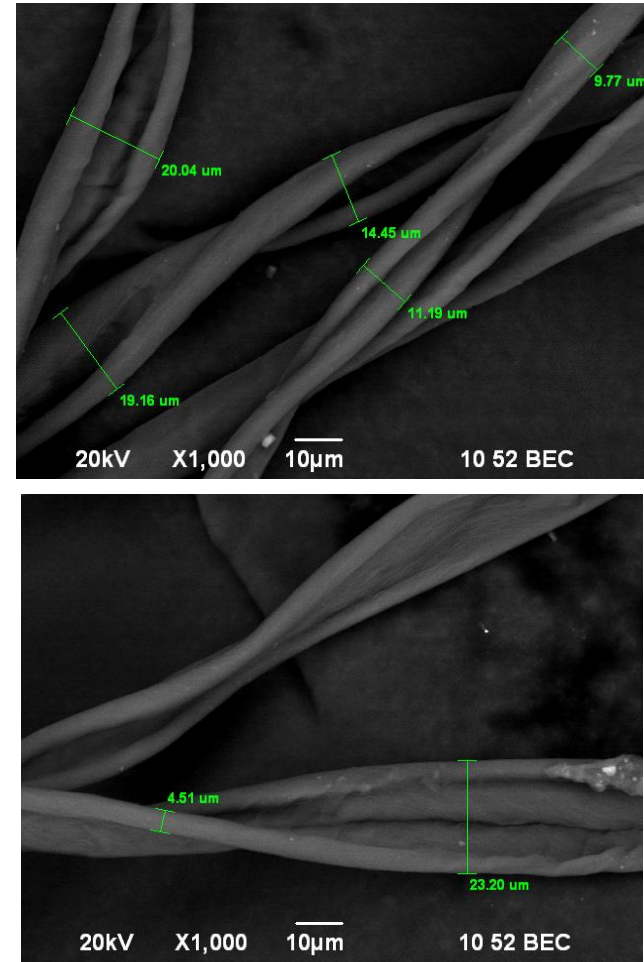
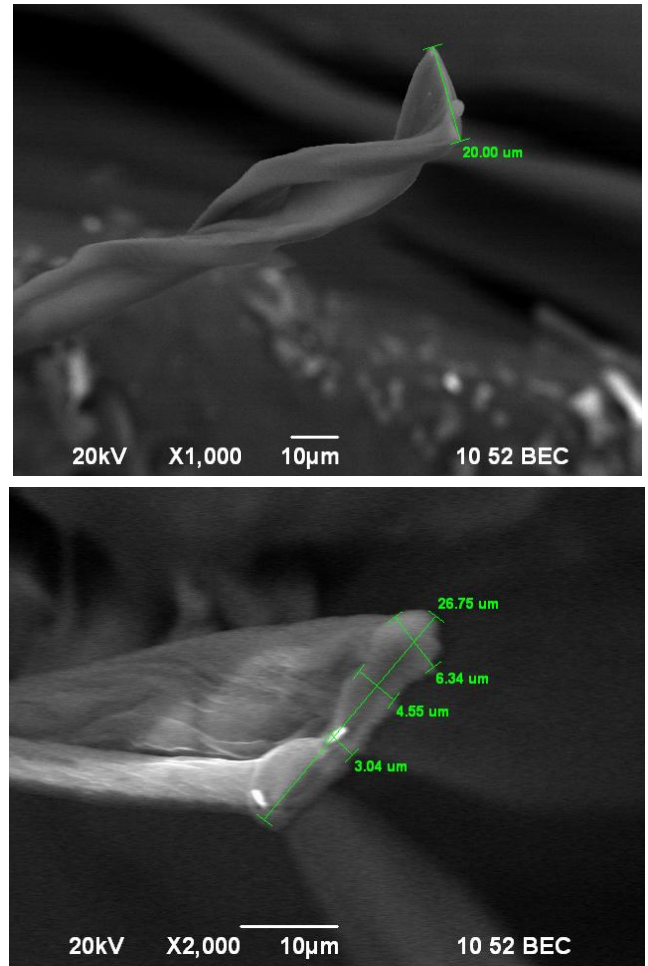

Fig. 1. Images of individual villi of cotton fiber (magnification of $\times 1000$ )

The equivalent diameter $d_{e}$ of pores and channels through which the heat agent is filtered is determined by the dependence (2):

$$
d_{e}=\frac{4 \cdot \varepsilon_{l}}{a}
$$

here $\varepsilon_{l}$ is a porosity of the layer, $\mathrm{m}^{3} / \mathrm{m}^{3} ; a$ is an active specific surface of the layer, $\mathrm{m}^{2} / \mathrm{m}^{3}$;

As it was mentioned above, when applying the pressure drop, the height of the layer is decreased, that affects the change of equivalent diameter and the active specific surface. The initial specific surface area of cotton fiber $a_{0}$ depends on the initial height of the cotton fiber layer and its volume:

$$
a_{0}=\frac{F}{H_{0} \cdot S}
$$

where $H_{0}$ is the initial height of the cotton fiber layer, m; $S$ is the cross-sectional area of the experimental container, $\mathrm{m}^{2}$.

To determine the initial specific surface area of all cotton villi $a_{0}$, it was assumed that $N$ identical villi with an average length of $L_{v}$ were in the experimental container. Then the external surface of all particles can be represented as:

$$
F=2(a+b) \cdot L_{v} \cdot N
$$

where $a$ and $b$ are the average width and thickness of the cotton villus, respectively, $\mathrm{m}$.
Knowing the density of cotton fiber $\rho_{v}$ and the weight of the sample $G_{v}$, we found the volume of cotton fiber $V$ :

$$
V=\frac{G_{v}}{\rho_{v}}=a \cdot b \cdot L_{v} \cdot N
$$

Then the number of villi $N$ was determined:

$$
N=\frac{G_{v}}{\rho_{v} \cdot a \cdot b \cdot L_{v}}
$$

The surface of all cotton villi was determined in accordance with Eq. (7)

$$
F=2 \cdot(a+b) \cdot L_{v} \cdot \frac{G_{v}}{\rho_{v} \cdot a \cdot b \cdot L_{v}}=\frac{2 \cdot(a+b) \cdot G_{v}}{\rho_{v} \cdot a \cdot b}
$$

The initial and running specific surfaces at the initial and running heights of the cotton fiber were found as the ratio of the total surface area of all villi to the volume they occupy in the experimental container:

$$
a_{0}=\frac{F}{H_{0} \cdot S}=\frac{2 \cdot(a+b) \cdot G_{v}}{\rho_{v} \cdot a \cdot b \cdot S \cdot H_{0}}
$$

and the running specific surface of the cotton fiber was represented in the form:

$$
a=a_{0} \cdot \frac{H_{0}}{H}
$$

where $a_{0}$ and $a$ are the initial and running specific surfaces of the fiber layer, $\mathrm{m}^{2} / \mathrm{m}^{3} ; H_{0}$ is the initial height of the fiber layer, $\mathrm{m} ; H$ is the running height of the fiber layer, depending on the pressure loss, $\mathrm{m}$. 
Considering the given dependencies, the specific surface of the cotton fibers is written in the form:

$$
a=\frac{2 \cdot(a+b) \cdot G_{v}}{\rho_{v} \cdot a \cdot b \cdot S \cdot H_{0}} \cdot \frac{H_{0}}{H}=\frac{2 \cdot(a+b) \cdot G_{v}}{\rho_{v} \cdot a \cdot b \cdot S \cdot H}
$$

Let us express the weight of the cotton fiber sample by its volume and density:

$$
G_{v}=V \cdot \rho_{v}=H_{v} \cdot S \cdot \rho_{v}
$$

where $H_{v}$ is the height of the cotton fiber layer with density $\rho_{v}, \mathrm{~m}$.

The running specific surface of the layer of cotton fiber can be represented in the form:

$a=\frac{2 \cdot(a+b) \cdot G_{v}}{\rho_{v} \cdot a \cdot b \cdot S \cdot H}=\frac{2 \cdot(a+b) \cdot H_{v} \cdot S \cdot \rho_{v}}{\rho_{v} \cdot a \cdot b \cdot S \cdot H}=\frac{2 \cdot(a+b)}{a \cdot b} \cdot \frac{H_{v}}{H}$

and Eq. (2) can be written as:

$$
d_{e}=\frac{4 \cdot \varepsilon_{l}}{a}=\frac{2 \cdot a \cdot b \cdot \varepsilon_{l}}{(a+b)} \cdot \frac{H}{H_{v}}
$$

The pressure loss determined by Eq. (1) using Eq. (13) can be represented as:

$$
\Delta P=\lambda_{l} \cdot \frac{H \cdot(a+b) \cdot H_{v}}{2 \cdot a \cdot b \cdot H \cdot \varepsilon_{l}} \cdot \frac{\rho v^{2}}{2}=\lambda_{l} \cdot \frac{(a+b) \cdot H_{v}}{2 \cdot a \cdot b \cdot \varepsilon_{l}} \cdot \frac{\rho v^{2}}{2}
$$

It is known that the coefficient of hydraulic resistance of the porous layer $\xi$ is defined as a part of the rate pressure, i.e. Eq. (14) can be represented as:

$$
\begin{gathered}
\Delta P=\zeta \cdot \frac{\rho v^{2}}{2}=\zeta \cdot \frac{\rho \cdot v_{0}^{2}}{2 \cdot \varepsilon_{l}^{2}} \\
\zeta=\lambda_{l} \cdot \frac{(a+b) \cdot H_{v}}{2 \cdot a \cdot b \cdot \varepsilon_{l}}
\end{gathered}
$$

where $v_{0}$ is the fictitious filtration rate of the heat agent $v_{0}=v \cdot \varepsilon, \mathrm{m} / \mathrm{s}$.

\subsection{Experimental Procedure}

All experiments were performed with corresponding aliquots of cotton fiber. Taking into account that the moisture content of natural cotton fiber is 0.08 $0.12 \mathrm{~kg} \mathrm{H} \mathrm{H}_{2} \mathrm{O} / \mathrm{kg}$ dry mat. and the moisture is mainly a bound one, for the gas flow temperature $T=293 \mathrm{~K}$ and relative humidity of air $\varphi=60 \%$ its evaporation will be negligible (the time of the experiment was $90-120 \mathrm{~s}$, the weight loss of the sample during the experiment was less than $0.2 \%$ ). So, the influence of moisture evaporation on the pressure loss was neglected.

Experimental studies of the cotton fiber layer hydrodynamics were carried out at the experimental setup shown in Fig. 2, according to the procedure given in [13].

The experimental unit consists of a container 1 mounted on the receiver 2 and connected with a liquidpacked vacuum pump 6 by pipes, rotameter 3 , shutoff valve 4 and control valve 5 . The vacuum created by the vacuum pump in the receiver and under the material layer is measured by a vacuum meter 7 .

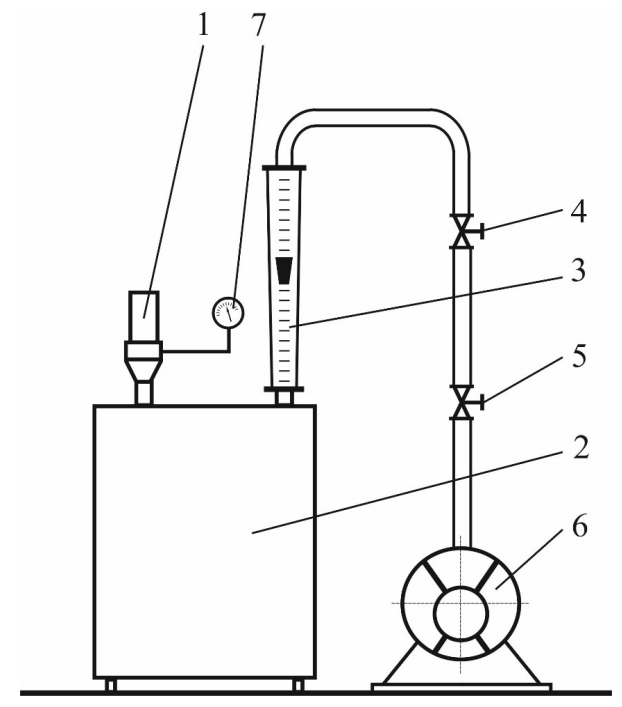

Fig. 2. The experimental setup for studying the pressure loss in the cotton fiber layer: experimental container (1), receiver (2), rotameter (3), shutoff and control valves $(4,5)$, vacuum pump (6) and vacuum meter (7)

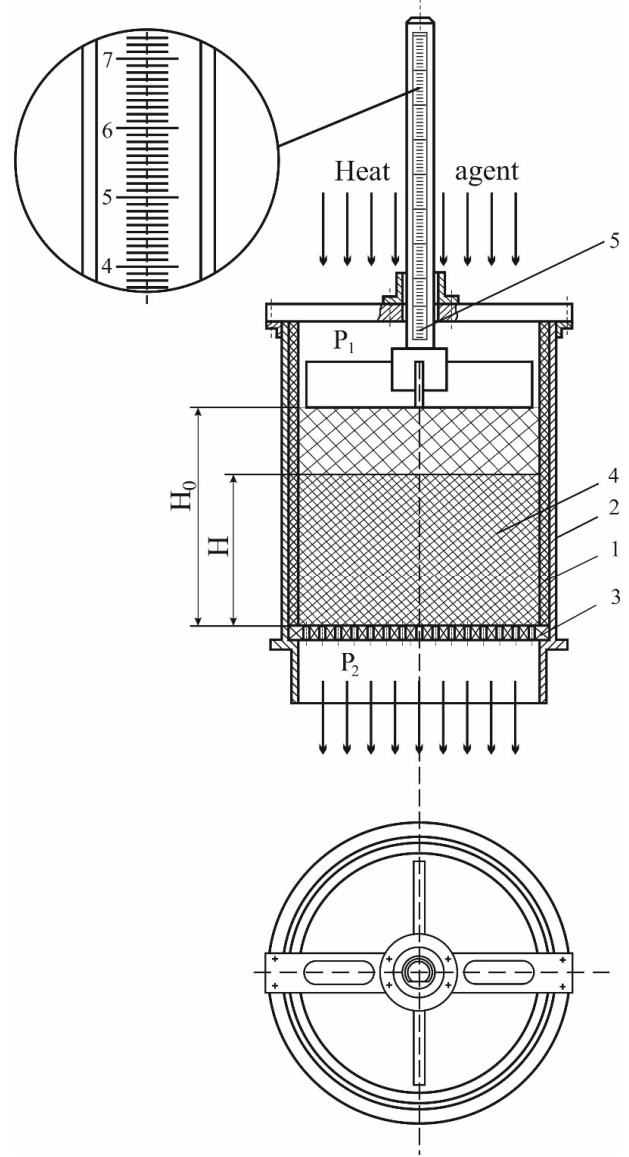

Fig. 3. Scheme of experimental container: container support (1); insulating insert (2); perforated baffle (3); layer of cotton fiber (4); measuring bar (5).

$H_{0}$ is the initial height of the cotton fiber aliquot, $H$ is the running height of the aliquot when pressure is changed 
The scheme of experimental container is represented in Fig. 3. The support of container 1 is made of duralumin; the cylindrical insert 2 and the perforated baffle 3 are made of heat-insulating material (fluoroplast). The measuring bar 5 located in the center of the container allows to determine the height of the layer 4 when the pressure drop is changed.

The experimental container 1 loaded with an aliquot of cotton fiber was mounted on the receiver 2 . After the vacuum pump 6 was switched on, different values of air flow rate through the layer of cotton fibers were set by means of control valve 5 . The flow rate was measured by the rotameter 3 , the pressure loss - by the vacuum meter 7 and the change in the layer height - by the measuring bar.

The measurements were carried out at 8-10 points. Every experiment was performed at least three times before obtaining stable data. A fresh sample of cotton was taken for every experiment. The aliquot weight was determined using the AXSIS-3000 electronic scales with an accuracy of $0.01 \mathrm{~g}$. In every experiment the initial bulk density for aliquots with the equal weight was the same. Initial data for experimental studies are shown in the Table.
Experimental results of the heat agent filtration through a layer of cotton fiber of different weights are presented in the form of functional dependence $\Delta P=f\left(v_{0}\right)$ and are shown in Fig. 4.The analysis of Fig. 4 shows that the curves are parabolic, that is, the pressure loss in the cotton fiber layer is affected by both viscous and inertial components.

The change in the layer porosity depending on the fictitious filtration rate of the heat agent $\varepsilon=f\left(v_{0}\right)$ is shown in Fig. 5. The increase in the fictitious filtration rate leads to the increase in the pressure loss, and consequently to the increase in the layer porosity due to the decrease in its height.

Approximating the experimental data with a degree function, we obtain the following dependence for determining the running porosity of the layer, depending on the initial porosity $\varepsilon_{0}$ and fictitious filtration rate:

$$
\varepsilon=\varepsilon_{0} \cdot v_{0}^{-0.025}
$$

The comparison of experimental data and results calculated according to Eq. (17) is shown in Fig. 6. As can be seen from Fig. 6, the absolute value of the maximum relative error between the experimentally determined and theoretically calculated values does not exceed 5.6\%.

\section{Cotton fiber layer characteristics}

\begin{tabular}{|c|c|c|c|c|}
\hline $\begin{array}{c}\text { Weight of the } \\
\text { sample } G_{v}, \mathrm{~kg}\end{array}$ & $\begin{array}{c}\text { The initial porosity of } \\
\text { the layer } \varepsilon_{0}, \mathrm{~m}^{3} / \mathrm{m}^{3}\end{array}$ & $\begin{array}{c}\text { The surface of all } \\
\text { cotton villi } F, \mathrm{~m}^{2}\end{array}$ & $\begin{array}{c}\text { The height } H_{v} \text { of the fiber } \\
\text { layer with the density } \rho_{v}, \mathrm{~m}\end{array}$ & $\begin{array}{c}\text { The total length of all } \\
\text { cotton villi } L, \mathrm{~m}\end{array}$ \\
\hline 0.010 & 0.990 & 3.448 & 0.00101 & 58824 \\
\hline 0.015 & 0.987 & 5.172 & 0.00151 & 88235 \\
\hline 0.020 & 0.986 & 6.897 & 0.00201 & 117647 \\
\hline 0.025 & 0.984 & 8.621 & 0.00252 & 147059 \\
\hline 0.030 & 0.981 & 10.345 & 0.00302 & 176471 \\
\hline 0.060 & 0.966 & 20.689 & 0.00604 & 352941 \\
\hline 0.080 & 0.955 & 27.586 & 0.00806 & 470588 \\
\hline 0.110 & 0.942 & 37.931 & 0.01108 & 647059 \\
\hline
\end{tabular}

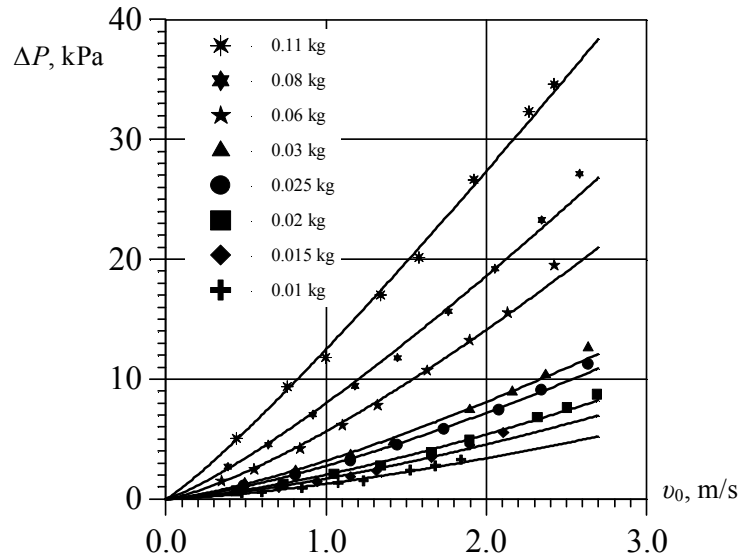

Fig. 4. Pressure loss in the cotton fiber layer vs. the fictitious filtration rate of the heat agent at different weights of the sample

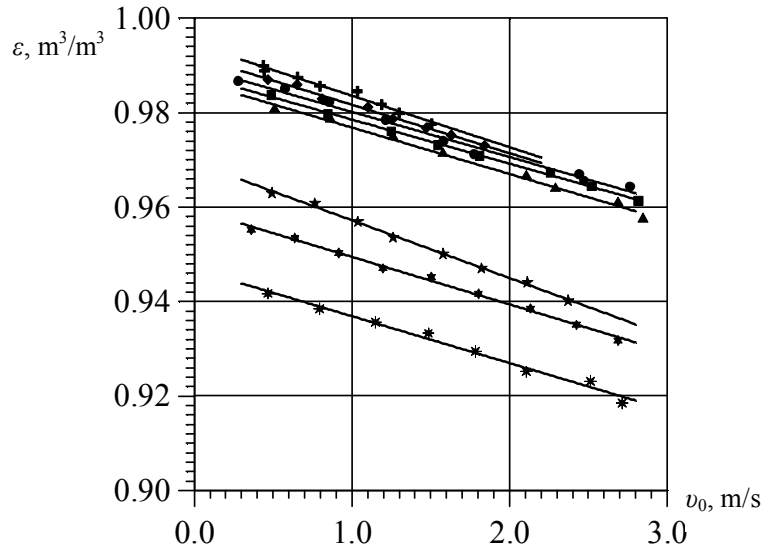

Fig. 5. Porosity of the cotton fiber layer $v$ s. the fictitious filtration rate of the heat agent (symbols are the same as for Fig. 4) 


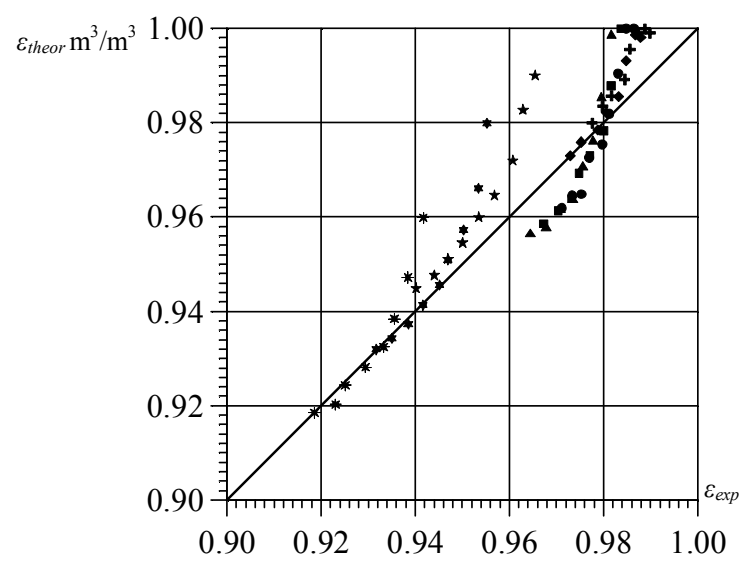

Fig. 6. Comparison of experimental and theoretically calculated values of the cotton fiber layer porosity according to Eq. (16) (the symbols are the same as for Fig. 4)

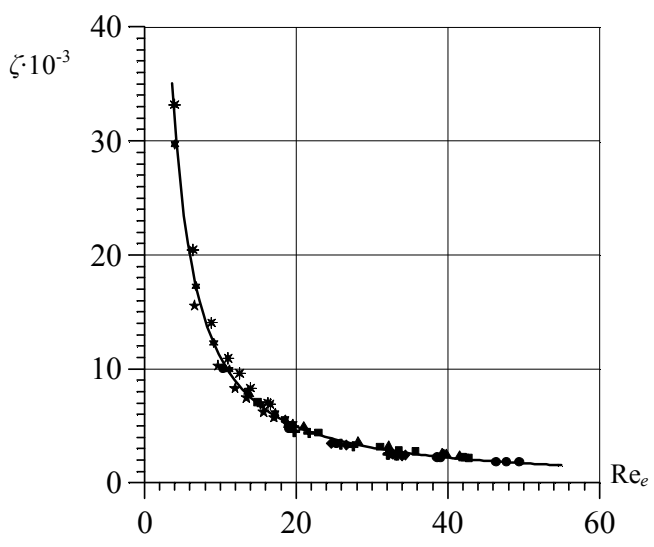

Fig. 8. Hydraulic resistance coefficient of the cotton fiber $v$ s. the Reynolds number (symbols are the same as for Fig. 4)

The generalization of the experimental data (Fig. 4) was carried out in the form of dimensionless complexes: dependence of the Euler number $\left(\mathrm{Eu}=\Delta P /\left(\rho \cdot v^{2}\right)\right)$ on the Reynolds number $\left(\mathrm{Eu}=f\left(\operatorname{Re}_{e}\right)\right)$ (Fig. 7), and the dependence of the layer hydraulic resistance $\zeta=f\left(\mathrm{Re}_{e}\right)$ on the Reynolds number (Fig. 8).

Approximation of the experimental data by a degree function (Fig. 7) made it possible to obtain the following dependence:

$$
E u=84000 \cdot \mathrm{Re}_{e}^{-1.18}
$$

where $\mathrm{Re}_{e}$ is the equivalent value of the Reynolds number.

$$
\operatorname{Re}_{e}=\frac{v \cdot d_{e} \cdot \rho}{\mu}
$$

where $\mu$ is the coefficient of dynamic viscosity of the gas flow, $\mathrm{Pa} \cdot \mathrm{s}$.

The coefficient of hydraulic resistance of the cotton fiber layer was calculated according to Eq. (15) using the experimental data given in Fig. 4. Approximation of the

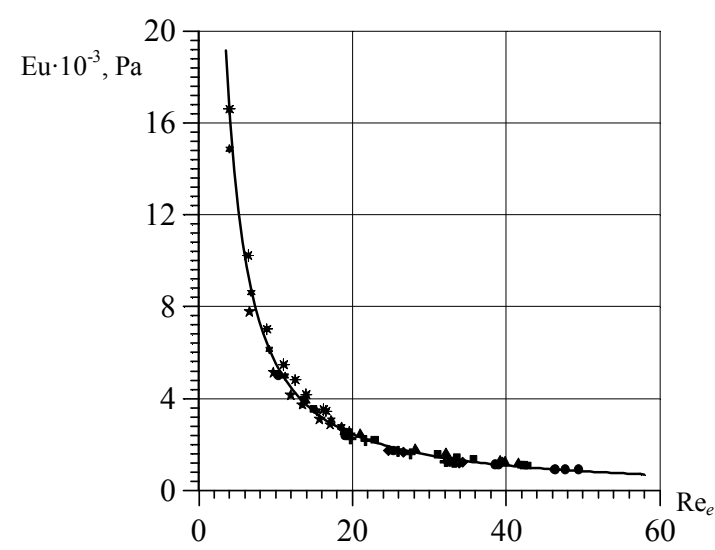

Fig. 7. The dependence of the Euler number on the Reynolds number (symbols are the same as for Fig. 4)

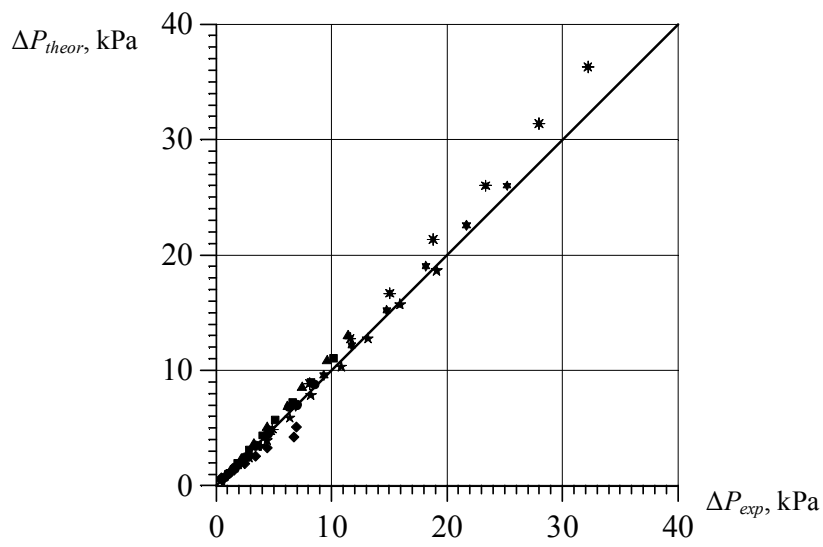

Fig. 9. Comparison of experimental and theoretically calculated pressure loss in a layer of cotton fiber (symbols are the same as for Fig. 4)

experimental data by a degree function (Fig. 8) made it possible to obtain the following dependence:

$$
\xi=160000 \cdot \operatorname{Re}_{e}^{-1.16}
$$

The comparison of experimental data and results calculated according to Eq. (18) is shown in Fig. 9. The absolute value of the relative error does not exceed $14.2 \%$, which is explained by the complex structure and spontaneous formation of the cotton fiber layer, as well as the effect of the pressure drop on the layer height.

\section{Conclusions}

The obtained dimensionless dependence of the Euler number on the Reynolds number allows to predict the energy costs necessary to create the pressure drop (under the same hydrodynamic conditions); it is suitable during the design of new drying equipment. The dependence of hydraulic resistance coefficient of the cotton 
fiber on the Reynolds number can be used when technological parameters need to be changed, for example, the height of the cotton fiber layer or the filtration rate of the heat agent. The error between theoretically calculated values and experimental data does not exceed $14.2 \%$, which is quite acceptable for the design of the new drying equipment.

\section{References}

[1] Kale R., Bansal P., Gorade V.: J. Polym. Environ., 2017, 26, 355. https://doi.org/10.1007/s10924-017-0936-2

[2] Zeng L., Zhao S., He M.: J. Power Sour., 2018, 376, 33. https://doi.org/10.1016/j.jpowsour.2017.11.071

[3] Cui L., Shi S., Hou W. et al.: New Carbon Mater., 2018, 33, 245. https://doi.org/10.1016/s1872-5805(18)60337-3

[4] Sousa L.: Estudo da Secagem de Materiais Texteis

Monografiade Qualificac,a a para Doutorado Maringaa, BR, 2000.

[5] Yin C., Li J., Xu Q. et al.: Carb. Polym., 2007, 67, 147.

https://doi.org/10.1016/j.carbpol.2006.05.010

[6] Lv N., Wang X., Peng S. et al.: RSC Adv., 2018, 8, 30257.

https://doi.org/10.1039/c8ra05420g

[7] Karavaikov V., Borzov V.: Technol. Tekstil. Prom., 2007, 4, 95.

[8] Boltaboev S., Parpiev A. Sushka Khlopka-Syrtsa. Ukituvchi,

Tashkent 1980.

[9] Shaikhov E., Normuhammedov N. et al.: Pakhtachilik. Mehnat, Tashkent 1990.

[10] Luiza H., Oswaldo C., Nehemias C.: Dry. Technol., 2006, 24, 485-497. https://doi.org/10.1080/07373930600611984

[11] Matkivska I., Gumnytskyi Y., Atamanyuk V.: Chem. Chem. Technol., 2014, 8, 359. https://doi.org/10.23939/chcht08.03.359

[12] Atamanyuk V., Huzova I., Gnativ Z::Chem. Chem. Technol., 2018, 12, 263. https://doi.org/10.23939/chcht12.02.263

[13] Atamanyuk V., Gumnytskyi J.: Naukovi Osnovy Filtratsijnogo Sushinnia Dyspersnykh Materiliv. Vyd-vo NULP, Lviv 2013.

[14] Gelperin N.: Osnovnye Processy i Apparaty Khimicheskoi Technologii. Khimia, Moskva 1981.

Received: April 10, 2019 / Revised: August 29, 2019 / Accepted: December 18, 2019

\section{ГІДРОДИНАМІКА ФІЛЬТРАЦІЙНОГО ВИСУШУВАННЯ БАВОВНИ}

Анотація. Приведені результати щзодо використання волокна бавовни, як найбільш чистої і натуральної челюлози, сировини для виробництва різноманітних хімічних продуктів. Обтрунтовано необхідність підготовки волокна бавовни для ї̈ використання у хімічній промисловості та доиільність ї̈ висушування фільтраційним методом. Експериментально досліджено геометричні параметри окремих ворсинок бавовни, фізико-механічні характеристики шару. Аналітично визначено вплив зміни висоти стаміонарного шару, під час прикладання перепаду тисків, на зміну порізності, еквівалентного діаметру каналів в шарі крізь який фільтрується тепловий агент, питому поверхню і втрати тиску під час фільтраційного висушування. Представлено результати експериментальних досліджень втрат тиску під час фільтрачійного висушування, з точки зору внутрішньої задачі гідродинаміки.

Результати експериментальних досліджень щуодо фільтрування теплового агенту крізь шар бавовни за різної маси i різних висот шару представлені у вигляді функціональної залежності $\triangle P=f\left(v_{0}\right)$, а зміни порізності шару волокна бавовни $\varepsilon=f\left(v_{0}\right)$. Узагальнення експериментальних даних гідродинаміки фільтрування теплового агенту крізь шар бавовни проведено у вигляді безрозмірних комплексів $E u=f(R e)$, a залежність коефіцієнту гідравлічного опору шару як функиіі числа Рейнольдса $\xi=f(R e)$. Отримані результати в безрозмірній формі дають змогу прогнозувати енергетичні затрати на створення перепаду тисків (за однакових гідродинамічних умов) під час проектування нового сушильного обладнання.

Ключові слова: гідродинаміка, фільтрачійне висушування, критеріальні залежності, волокно бавовни. 